to the stern demands of economic necessity, so that there is likely to be a serious shortage of plant for an indefinite number of years.

When assessing the need for future extensions, an estimate is required of the availability of existing plant, and some striking figures are given indicating that the technical advance in operating conditions has carried with it a general reduction in availability, so that breakdowns are more frequent on modern than on older plant. Leading sources of trouble are said to be turbine-blading failures due to vibration, and alternator rotor failures due to copper distortion, both of which are the subject of intensive research. Also responsible for reduced availability, as well as reduced output capacity, is the supply of unsuitable and low-grade fuels to the boiler plant, a war-time inheritance which persists in spite of the very great increase in the price of fuel.

Proceeding to the short-term planning associated with the daily operation of the Grid system, the paper reveals that the system was originally designed to operate as seven independent sections, and it was not until the load position in some areas had become very grave in 1939 that it was decided to try the experiment of operating the whole of the system in parallel. This operation was successful and has been continued ever since, though the possibility of sequential tripping of lines, accentuated by the existence of only two interconnectors between the north and south of Great Britain, has demanded careful consideration.

After an interesting description of the sequence of events in the planning of a single day's operation of this complex system, from the nerve centre at national control in constant communication with the seven area controls, the paper concludes with a brief review of future developments. The most significant changes foreseen are the introduction of the gas turbine for peak-load working, and of atomic energy for base-load generation. Here it is of interest to turn again to the report of the Central Electricity Board, which is able to cite the arrangements the Board has made for the installation of two $15,000 \mathrm{~kW}$. gas turbine sets, at Dunston and Stretford respectively; though the application of atomic energy remains a subject for study, and a hope for the future.

R. W. HAYWOOD

\section{MOSSES AS SOIL INDICATORS}

$I^{T}$

$\mathbf{T}$ is pleasing to see that the attention of foresters 1 is being directed to the mosses as indicators of soil conditions. H. Watson, forest officer instructor at the Benmore Forest School, Argyll, has produced an attractive booklet introducing this subject (Forestry Commission Booklet No. 1. Woodland Mosses. London: H.M. Stationery Office, 1947. $2 s$, net).

The brief introductory account of the life-history of a moss is followed by descriptions of twelve species likely to be encountered in afforestation areas. The descriptions are accompanied by 'turf' photographs to show the habit of growth in mass, and photographs of single shoots to illustrate the more detailed growth. form and include the salient features by which the species may be recognized in the field. There are also notes on the soil conditions favoured, especially as regards the degree of humus decomposition and soil acidity, and brief reference is made to the suitability or otherwise of the soil conditions indicated for afforestation purposes.
The mosses constitute a fascinating group of plants of which all too little is known. Many of them, after a little experience, can be recognized in the field by the naked eye or with the use of a hand lens, and type specimens may be kept dry in packets and soaked out again when required. Forest officers should be in a position to extend considerably our knowledge of the soil conditions indicated by the presence of particular moss species along the lines of the present booklet; and the recent production by Johnson and Sons, Ltd., of Hendon, N.W.4, of Universal and Comparator Test-papers for the measurement of $p H$ values to within $0.3 p H$, provides a very simple method for estimating the soil acidity with some degree of exactitude. Information of this kind would not only be of value to practical foresters, but would also extend our knowledge of this group of plants.

The British Bryological Society has recently asked its members to make observations on mosses with particular reference to times of production of capsules and reproductive organs in different carefully recorded localities and altitudes. The time of capsule production offers no difficulty, and in many cases the reproductive stage may be recognized by the opening of the antheridial cups, as illustrated in the booklet for Mnium hornum. It is to be hoped that foresters will be attracted by this aspect of ecology and that Forestry Commission Booklet No. 1 will be followed by others.

\section{FORTHCOMING EVENTS}

(Meeting marked with an asterisk * is open to the public)

Monday, May 24

LINNEAN SOotrTy of LONDON (at Burlington House, Piccadilly, London, W.1), at 4.30 p.m.- Anniversary Meeting.

ROXAL GROGRAPHTAL SOOIRTY (at Kensington Gore, London S.W.7), at 5.30 p.m.-Mr. E. W. Gilbert : "The Boundaries of Loca Government Areas".

Tuesday, May 25

ROYAL ANTHROPOLOGICAL INSTITUTE (at 21 Bedford Square London, W.C.1), at 5 p.m. -Dr. E. R. Leach : "Some Features of Social Structure among Sarawak Pagans".

EUGENIOS SOcrimY (at the Royal Society, Burlington House, Piccadilly, -London, W.1), at 5.30 p.m.-Prof. Brinley Thomas: "Migration and the British Commonwealth".*

Soomery OF INSTRUMRAT TECHNOLOGY (at the Royal Society of Tropical Medicine and Hygiene, Manson House, 26 Portland Place, London, W.1), at 6.30 p.m.-Annual General Meeting; Mr. J. K. Burkitt: "Proposed System in Instrumentation Symbols".

Wednesday, May 26

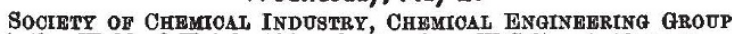
(at the Waldorf Hotel, Aldwych, London, W.C.2), at 12 noon.Annual General Meeting.

ROYAL MIOROSOOPICAL SOCTETY, SEOTION OF INDUSTRIAL MTOROsoopY (at B.M.A. House, Tavistock Square, London, W.C.1), at 6 p.m. -Dr. K. M. Greenland": "Principles of Interferenee Films used in Optical Instruments".

Thursday, May 27

ROYAL SOctETY (at Burlington House, Piccadilly, London, W.1), at 4.30 p.m. $\rightarrow$ Sir Edward Salisbury, F.R.S.: "The Royal Botanic Gardens, Kew".

ROYAL STATISTHOAL SOCTETY, RHEEAROH SBOTION (at the London School of Hygiene and Tropical Medicine, Keppel street, London, W.C.1), at 5.15 p.m.-Mr. D. G. Champernowne: "Sampling Theory pplied to Autoregressive Sequences".

ROYAL AERONAUTTCAL SOOIRTY (at the Institution of Civil Engineers, Great George Street, London, S.W.1), at 6 p.m.-Mr. A. Gouge : The 36th Wilbur Wright Memorial Lecture.

\section{Friday, May 28}

SOOIETY OF CHEMICAI INDUSTRY, FOOD GROUP (joint meeting with the ROYAL SANITARY INSTITUTR, at the Royal Hall, Ripon Road, Harrogate), at 10 a.m. -Discussion on "The Cleaning and Sterilizing

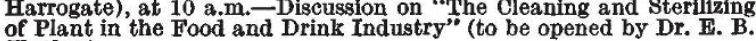
Hughes).

INSTIPOTR OP PHYSIOS, ELEOTRONIOS GROUP (joint meeting with the INDUSTRIAL SPFOTROSOOPIO GROUP, at 47 Belgrave Square, London, S.W.1) at 2.30 p.m.-Discussion on "The Application of ElectronMultipliers to spectroscopy". 